\title{
ZAGADNIENIE AUTENTYCZNOŚCI W KONSERWACJI HISTORYCZNYCH OBSZARÓW MIEJSKICH
}

\begin{abstract}
Uchwycenie autentyczności miasta gwarantuje właściwy sposób jego zarządzania, zarówno od strony zabiegów konserwatorskich, jak i planowanych działań architektonicznych oraz urbanistycznych. W artykule przeanalizowano warunki oraz poziomy, na których manifestuje się autentyczność miasta a także poddano identyfikacji sposoby na jakie owa manifestacja jest wyrażona. Rozpoznano również jak ten proces może być sfalsyfikowany i oceniony.
\end{abstract}

Słowa kluczowe: miasto, autentyczność, tożsamość, ochrona

\section{Wprowadzenie}

Koncept 'autentyczności' rozumianej jako podstawowy aspekt działań zmierzających do zachowania dziedzictwa kulturowego w sposób niezwykle wyraźny odcisnął swe piętno na teorii konserwacji końca XX wieku. W konsekwencji miał on znaczący wpływ na współczesne tendencje w kształtowaniu przestrzeni historycznych miast. Jednakowoż to właśnie w przypadku zabytkowych założeń urbanistycznych poszukiwania autentyczności ich tożsamości okazały się być zadaniem niezwykle kompleksowym i niejednokrotnie niedającym się jednoznacznie uchwycić. Wynika to bezpośrednio z charakterystycznej dla założeń miejskich konstruktywnej dynamiki zawartej w procesie ich naturalnego kształtowania się w czasie, co przejawia się między innymi w takich wymiarach jak zanik granic terytorialnych obecnych metropolii czy gentryfikacja ich historycznych obszarów.

Jednocześnie jako takie rozpoznanie autentyczności wydaje się być niezbędnym dla wyznaczenia esencjalnej kondycji właściwego i efektywnego procesu ochrony założenia historycznego obszaru miejskiego. Tym samym konieczną jest weryfikacja warunków oraz poziomów na których autentyczność

\footnotetext{
${ }^{1}$ Tomasz Tomaszek, Politechnika Rzeszowska, Katedra Konserwacji Zabytków, al. Powstańców Warszawy 12,35-959 Rzeszów; tel.: 17743 2105; e-mail: ttomasz@prz.edu.pl
} 
miasta się manifestuje, a także identyfikacja sposobu w jaki owa manifestacja jest wyrażona oraz uchwycenie jak ten proces może być sfalsyfikowany i oceniony [8].

\section{Autentyczność jako prawdziwość uprawomocniana na poziomie intersubiektywnym}

Koncept autentyczności odnosi się do pojęcia ‘prawdziwości' rozumianej jako bycie prawdziwą ewidencją czegoś, a także przynależnością do konkretnej ludzkiej kreacji [8]. A zatem 'autentyczność' jest w bezpośredniej relacji z wyobrażeniem o prawdzie, którą Jokilehto uważa za historycznie uwarunkowane pojęcie [5], którym w świecie kultury zachodniej do czasów średniowiecza rządziły społeczne konwencje oraz prawa boskie. Tym samym na horyzoncie tak ujmowanej prawdy pojawiała się jej dostępna wszystkim obiektywność. Sytuacja jednakowoż uległa przemianie wraz z pojawieniem się człowieka nowoczesnego, co szczególnie zauważalne jest obecnie w czasach postmodernistycznych, kiedy to przyznaje się istnienie nieredukowalnej wielokrotności sposobów interpretacji rzeczywistości [3].

Jak zauważa Taylor człowiek dąży do skonstruowania swojej autentycznej tożsamości dla siebie samego i kiedy ten proces nie zostaje całkowicie z sukcesem zrealizowany czuje się on pozbawiony szczególnego poczucia bezpieczeństwa. To skutkuje przeniesieniem jego zawierzenia w stronę nauki, szeroko pojętej duchowości czy też kreacji artystycznej [7]. To sztuka staje się wehikułem pozwalającym na ekspresję istoty człowieczeństwa, co w konsekwencji prowadzi do nadania w procesie kreacji szczególnej wartości każdemu niepowtarzalnemu w swej naturze dziełu sztuki. To właśnie odróżnia dzieło sztuki od jego repliki. I tak możemy założyć, że im więcej obiekt reprezentuje kreatywną i innowacyjną kontrybucję, tym jest on bardziej prawdziwym oraz bardziej autentycznym [5].

Powołując się na Ferrara należy przyjąć, iż 'autentyczność' wymaga uniwersalnego usankcjonowania (uprawomocnienia) zasadzającego się na intersubiektywnym osądzie, nie ignorującym jednocześnie pluralizmu i różnic stojących u jego podstaw. Taki argument ukazuje koncept 'autentyczności' w stosunku do obiektu sztuki ujmowanego jako ekspresja istoty człowieka. Tym samym Ferrara proponuje pojęcie 'refleksyjnej autentyczności'. Oznacza to, iż pomimo iż jest ona subiektywna kiedy dotyczy poszukiwania indywidualnej ekspresji czy tożsamości, jest jednakowoż zasadniczo intersubiektywna bowiem odnosi się do kolektywnej świadomości społecznej. Dzieje się tak, bowiem zakłada ona trzy warunki: Pierwszy odnosi się do konstruowania tożsamości jednostki, która jest dzielona z innymi indywiduami (jednostkami). Drugi dotyczy samorealizacji, która wymaga wiedzy o innych. I w końcu trzeci odnosi się do refleksyjnej oraz intersubiektywnej oceny, a tym samym jej potwierdzenia (uprawomocnienia) [3]. 


\section{Założenie miejskie jako 'artefakt'}

Miasto może być definiowane oraz jednocześnie analizowane jako pewien polisemiczny twór o niezwykle złożonej naturze. Chociaż często jest opisywane z perspektywy wielu indywidualnych wymiarów - by wspomnieć tylko te najczęściej przytaczane jak społeczny, polityczny, ekonomiczny czy środowiskowy - hermeneutyka tego typu nie wyczerpuje jednak jego niezwykle złożonego fenomenu. Wydaje się wręcz, że próba jakiegokolwiek wyjaśnienia miasta poprzez wybrany aspekt przeczy jego naturalnemu, dynamicznemu charakterowi.

W najprostszym ujęciu miasto jako takie stanowią struktury materialne, naturalne oraz wybudowane, a także międzyludzkie relacje. Owe struktury i relacje rozpoznawane są jako znaczące jednostki związane ze specyficznym sposobem budowania, życia oraz bycia, a tym samym są ujmowane jako esencjalne części zrozumiałej całości. W konsekwencji wyróżnić można dwa aspekty miasta, mianowicie materialny i niematerialny, które pomimo różnic są jednakowoż ściśle ze sobą połączone. Ich faktyczna jedność przejawia się dla Phillipot w rozumieniu autentyczności konkretnego artefaktu, bowiem autentyczność dotyczy zarazem wewnętrznej jednostki procesu mentalnego odpowiedzialnego za powstanie danego artefaktu, jak i jego ostatecznej materialnej realizacji [6].

Nawiązując do wcześniejszych uwag a tym samym spostrzeżeń Ferrara należy przyjąć, iż w przypadku założenia miejskiego jako taka weryfikacja autentyczności następuje na poziomie kolektywnym. Inaczej mówiąc jest ona możliwa jedynie poprzez intersubiektywne rozpoznanie, za pomocą którego społeczność poszukuje oraz konkretyzuje swoje własne struktury autentyczności [8]. Tym samym dana społeczność miejska przeprowadza ową identyfikację w oparciu o zestaw reguł oraz wartości, które same w sobie pozostają zmienne w stosunku do upływu czasu historycznego. Dana wartość jest jednocześnie przyznana w danym miejscu poprzez wszelkie obecne oraz przeszłe aktywności, wspomnienia oraz wiedzę, a także społeczno-kulturowe relacje, które wydarzają się w przestrzeni i czasie [4]. I tak można postulować, że poszczególne generacje widzą autentyczność odmiennie i to bezpośrednio odzwierciedla ich potrzebę prawdy, ustalonych standardów oraz doktryn używania i hermeneutyki ich dziedzictwa kulturowego [8].

Jednocześnie podstawową przesłanką w dyskusji dotyczącej autentyczności miasta jest spostrzeżenie, iż miasto jest sumą atrybutów mogących być uznawanymi jako prawdziwe, lub też jako nieprawdziwe. A zatem konceptualizacja miasta w jego 'autentycznym stanie' wymaga uznania, że jest ono artefaktem: i) ludzkiego geniuszu, ii) pojedynczym, specyficznym i niezwykłym, oraz iii) o lokalnej i potencjalnie uniwersalnej reprezentatywności [8]. Mając na względzie powyższe, miasto powinno być po pierwsze formą kolektywnego, ludzkiego artefaktu, zbudowanego dzięki i za pomocą jego wewnętrznej, kreatywnej i transformującej sile, a zatem mocy decydującej co ma być modyfikowane, a co zachowane. Po wtóre miasto (lub jego część) powinno uzewnętrzniać osobli- 
wość i specyficzność, które pozwalają odróżniać go od niezliczonych innych przykładów. Taka cecha jest nieodłączną dla jego, czyli miasta, nie-przeciętnego charakteru, i jest wyrażona $\mathrm{w}$ jego istocie jako oryginalnej reprezentacji. I w końcu po trzecie, miasto powinno być rozumiane jako fundamentalny punkt odniesienia dla obserwacji zarówno lokalnych specyfik jak i jego potencjalnej uniwersalności [8].

Niemniej jednak rozpoznanie miasta jako jedności w postaci pojedynczego artefaktu jest w zasadzie niemożliwe, bowiem w rzeczy samej stanowi ono zazwyczaj kompleks ściśle złączonych, poszczególnych 'miejskich artefaktów'. Tym samym, jak proponują Zancheti, Lira oraz Piccolo, w celu weryfikacji autentyczności owych 'klastrów artefaktów stanowiących miasto', konieczne jest aby one odzwierciedlały: [i] Artefakt jako kreację, ponieważ wtedy emanuje $\mathrm{z}$ niego stan bycia w relacji do tego jak był on uformowany; [ii] Proces powstania $\mathrm{w}$ historii, artefakt jako uwiecznienie kreacji i procesu reprodukcji;[iii] Obecne zdolności ekspresji, 'ożywiony' artefakt, który jest rozpoznawany jako będący nośnikiem kolektywnych wspomnień i ekspresji relacji społecznych [8].

\section{Wymiary autentyczności miasta}

Jak to już wcześniej było postulowane, dyskusja dotycząca autentyczności miasta jest esencjalną dla krytycznej ewaluacji procesu konserwacji założeń urbanistycznych. Innymi słowy jest niezbędną dla właściwej konstrukcji sensów i rozpoznania wartości dziedzictwa urbanistycznego, a tym samym jego adekwatnej ochrony [8]. Jednocześnie w samym podejściu do dziedzictwa kulturowego istnieje zagrożenie ujmowania go jedynie $\mathrm{z}$ perspektywy jako takiego przemysłu turystycznego. W takim rozumieniu , mniej istotnym jest to co 'autentyczne' $\mathrm{w}$ ustanowionym historycznym sensie i wielkie znaczenie jest przyznawane temu co jest 'atrakcyjnie autentyczne"' [2]. Tym samym odbiorca obserwator-turysta nie jest włączony w ocenę czy identyfikację autentyczności, raczej jest ona prezentowana mu przez specjalistów za pomocą wcześniejszego planowania zawierającego założoną re-kreację oraz interpretację.

Należy zatem pamiętać, iż miasto jest wyznaczonym miejscem, obiektem ludzkiej kreacji, który kształtuje się w ewolucyjnym procesie wyrastającym z życia i dynamiki jego społeczności, i który posiada zdolności ekspresji swoich atrybutów. Mając na względzie powyższe uwagi uzasadnionym jest postulować, iż autentyczność miasta może być oceniana z poziomu trzech odrębnych, ale jednakowoż uzupełniających się wymiarów/poziomów [8]:

[I] Wymiaru/poziomu materialnego, referującego bezpośrednio do jego kreacji w postaci materiału rozpoznawanego jako dokument, w którym zanotowany jest konkretny „stan istnienia” założenia urbanistycznego. Wymiar materialny jest swoistym „ucieleśnieniem” kreatywnego aktu, który zostaje w postaci materialnej wpisany w dzieje historii, a zatem staje się poziomem 'żyjącej pamięci'. 
[II] Wymiaru/poziomu konstruktywnego, referującego do zdolności reprodukowania jego [miasta] budowlano-inwencyjnych dynamik, a zatem swoistego realizowania się konkretnego założenia urbanistycznego w czasie poprzez specyficzną „reprodukcję jego form”. Wymiar konstruktywny autentyczności odnosi się do procesu a nie do stanu, a zatem jego przedmiotem jest motor tej dynamiki. Tym samym poziom ten unaocznia autentyczność w odniesieniu do grupowego posiadania wiedzy 'jak budować'.

[III] Wymiaru/poziomu ekspresyjnego, w którym to fizyczne atrybuty miasta oraz proces kreacji i re-kreacji poprzez ich użycie zyskują swoisty wymiar symbolizujący sposób życia jego mieszkańców. To właśnie dzięki temu wymiarowi autentyczność może zostać rozpoznana inter-subiektywnie na poziomie społecznym (czyli przez społeczność danego miasta jak i też osób postronnych) [8].

\section{Wymiar materialny, konstruktywny i ekspresyjny jako konglomerat autentyczności}

Zdecydowana większość miast powstała na przestrzeni długiego okresu czasu, a zatem nie są one produktem pojedynczego aktu kreacji lub specyficznego, jednorazowego 'uformowania'. Tak samo jak miasto zyskuje swój 'kształt' $\mathrm{z}$ biegiem czasu, tak też $\mathrm{w}$ czasie jest równolegle transformowane w miarę kolejnych interwencji w jego 'budowlany materiał'. W konsekwencji miasta zazwyczaj składają się z szeregu różnych 'artefaktów' materiału budowlanego lub ich śladów, które nagromadziły się w historii. Tym samym założenie miejskie tak naprawdę konstytuują sukcesywne 'elementy materialne', które są ewidencją różnych aktów kreacji i transformacji oraz różnych epok czasowych i historycznych bezpośrednio decydujących o takiej a nie innej ewolucji miasta. Zasadniczo wszelkie akty kreacji, które są skrystalizowane w materialnych formach, dają się jednocześnie połączyć dzięki istniejącym pomiędzy nimi logicznym relacjom i czytelnym współzależnościom [8].

Miasto ukształtowane materialnie przez stanowiące je 'fragmenty' może być uznane za autentyczne jeżeli te fragmenty ukazują zdolność do reprezentowania autentycznego materiału stanowiącego integralną całość założenia urbanistycznego [8]. Dla uprawomocnienia autentyczności istotnym jest wobec tego rozpoznanie w jakim zakresie dany fragment umożliwia mentalnie 'odtworzenie' miejskiego obiektu który on, jako ów fragment, reprezentuje. W analizie tego problemu, czyli korespondencji pomiędzy częścią a całością, pomocnym może być zastosowanie kryteriów postulowanych przez CesareBrandi, a dotyczących ,potencjalnej jedności dzieła sztuki" [8]. To bowiem owa 'potencjalna jedność' gwarantuje integralność aktu twórczego jako takiego zrealizowanego w obiekcie, w którym poszczególne części tego aktu czy jego materialnej realizacji nie stanowią autonomicznych jednostek, ale są 'zrozumiałą całością' [1]. W konsekwencji jakiekolwiek miejska lacuna (ubytek w tkance miejskiej) nie jest tylko brakiem w fizycznym materiale, ale bezpośredni odnosi się do braku 
koordynujących elementów, które potencjalnie umożliwiają mentalną rekonstrukcję całości. I tak w przypadku braku pewnych elementów figuralnych następuje zagubienie lub też niemożność odczytania ciągłości i połączenia pomiędzy procesami ukształtowanymi w czasie. Takie braki to swoiste luki w całości, co bezpośrednio może zaburzyć potencjalną jedność 'obiektu' miasta i tym samym postawić pod znakiem zapytania jego autentyczność.

Jednocześnie już w samej hermeneutyce miasta możliwym jest bezpośrednie rozpoznanie sytuacji występowania braku jakiegoś elementu uznawanego za autentyczny, lub też wystąpienia konstytucji elementów obcych dla formalnego kontekstu. Takie ubytki lub wtrącenia mogą osiągnąć krytyczny punkt, kiedy zostaje zaburzona potencjalna jedność założenia miejskiego. Tym samym kompletność artefaktu miasta jako całości jest fundamentalnym warunkiem, dzięki któremu 'odczytanie' materialnej jedności miasta jest możliwe, a tym samym uznanie jego autentyczności.

Sytuacja kompletności struktury założenia miejskiego realizuje się na płaszczyźnie zdynamizowanej historycznym procesem zmiany zestawu wartości organizujących daną społeczność. Tym samym jakiekolwiek ingerencje zmieniające lub niwelujące materialne krystalizacje przeszłych systemów wartości stanowią istotną lukę w utrzymaniu tożsamości, a tym samym w konsekwencji autentyczności osady miejskiej. Dotyczy to chociażby likwidacji obiektów interpretowanych przez kolejne pokolenia jako potencjalnie 'nasyconych' dyskursem kojarzonym z negatywnym wspomnieniem dziejów historii. Przykładem może być niszczenie monumentów $\mathrm{z}$ czasów socrealizmu, tak popularne ostatnimi czasy na terenie Polski. W tej perspektywie zachowanie do dnia dzisiejszego Pomnika Czynu Rewolucyjnego (Pomnika Walk Rewolucyjnych) z roku 1974, znajdującego się w samym centrum Rzeszowa u zbiegu alei Łukasza Cieplińskiego i alei Józefa Piłsudskiego, jest nie tylko ewenementem wartym zauważenia, ale i też niezwykle istotnym czynnikiem uprawomocniającym autentyczność tego miasta jako konsekwentnego ciągu struktur architektonicznych oddających logikę czasu historycznego tych ziem.

Na poziomie/wymiarze konstruktywnym autentyczność może być oszacowywana natomiast za pomocą dekonstrukcji procesów konstrukcyjnych miasta, które są skrystalizowane w jego materialnym wymiarze. Procesy te mogą być odczytane bezpośrednio lub pośrednio z ich produktów, czyli reprezentacji fizycznych ujętych w materiale budowlanym. Aczkolwiek, o czym należy pamiętać, przy weryfikacji autentyczności miasta koniecznym jest równocześnie (obok odszyfrowania jego materialnej formalizacji) uchwycenie jej współzależności od perspektywy przestrzeni oraz czasowości (jako elementów ściśle z nią powiązanych).

Mając na względzie powyższe należy rozróżnić dwie możliwości kontynuacji procesu konstruktywnego w czasie historycznym [8]: I) sytuację, kiedy proces ten istniał w przeszłości i jest konsekwentnie kontynuowany do dzisiaj; II) sytuację, kiedy proces istniał $\mathrm{w}$ przeszłości i został ponownie zastosowany 
w czasie obecnym, po rozpoznawanym okresie przerwy w jego kontynuacji [8]. Tym samym sytuacja pierwsza odnosi się do kontynuacji specyficznego procesu konstrukcji miasta, druga natomiast do reprodukcji konkretnego procesu z przeszłości. W pierwszym przypadku pozwala to na utrzymanie i bezpośrednią kontynuację tradycyjnych zwyczajów (w tym konstrukcyjno-budowlanych), nawet jeżeli owa niezaburzona kontynuacja powiązana jest $\mathrm{z}$ naturalną i sukcesywną adaptacją nowych elementów oraz zwyczajów. W takiej perspektywie autentyczność jest uprawomocniana poprzez utrzymanie kontynuacji procesu bezpośrednio przynależnego do i rozpoznawanego przez 'daną społeczność'. Autentyczność zatem zostaje uznana za zachowaną, kiedy spełniony jest warunek kontynuacji danej tradycji z przeszłości i ów warunek w sposób nieprzerwany jest wypełniany w danej społeczności [6]. W przypadku drugim natomiast rozpoznany jako 'autentyczny' zostaje taki 'nowy' akt kreatywny, który bezpośrednio i logicznie jest odniesiony do konkretnego aktu kreatywnego z przeszłości. Jest on zarazem formą kreatywną odpowiadającą na obecny kontekst sytuacyjny, jak naturalnym odniesieniem do historii. I choć w zasadzie mówimy tu o 'nowym' procesie, to jednak jest on w sposób bezdyskusyjnie oczywisty zakotwiczony w esencji sposobu konstruowania w czasie historycznym, który to sposób wpłynął na konkretny wyraz materialny danego miasta.

A zatem postulowana kontynuacja lub wznowienie procesu konstruktywnego (a w konsekwencji poszczególnych praktyk konstrukcyjnych) jest warunkiem fundamentalnym dla uznania autentyczności w przypadku konkretnego miasta. Jednakowoż odczytanie samego 'oryginalnego' procesu może być niejednokrotnie bardzo utrudnione, bowiem jego identyfikacja ulega naturalnemu zaburzeniu wraz z upływem czasu. W takim przypadku jedynym świadectwem owego procesu pozostaje jego rezultat, czyli materialne realizacje wynikające $\mathrm{z}$ jego charakteru. W sytuacji skrajnej może nawet dojść do całkowitego zaniku procesu, i wówczas świadczą o nim tylko jego materialne wyniki. Wówczas poziom/wymiar autentyczności z konieczności zostaje zredukowany do poziomu materialności, bowiem - jak uważa Phillipot - kiedy rytuał się zakończył, to co pozostało, to materialny artefakt [6]. Niemniej jednak na podstawie zachowanych artefaktów, stanowiących bezpośrednie świadectwo charakteru historycznego procesu konstruktywnego, możliwym jest podjęcie próby odczytania oryginalnego procesu oraz odniesienie do autentyczności na tej właśnie podstawie. Jednakowoż, na co warto jednocześnie zwrócić uwagę, samo to 'skierowanie się’ do przeszłości może mieć dwojaki charakter - bezpośredni, kiedy wychodzimy od zachowanych artefaktów czy też ich części, lub pośredni, kiedy danych dostarczają jedynie teksty czy też inne materiały źródłowe (czego najlepszym przykładem może być rekonstrukcja Warszawy, wykonana głównie na podstawie zachowanych, historycznych wizerunków) [8].

Mając na względzie powyższe należy zauważyć, iż istnieje poważne niebezpieczeństwo zafałszowania autentyczności jako takiej poprzez implikację 'nietradycyjnych zachowań' konstruktywnych wynikających bezpośrednio 
z postępującej globalizacji. Zjawisko owo może być już z sukcesem obserwowane $\mathrm{w}$ zasadzie we wszelkich obszarach kulturowych, gdzie lokalne tożsamości materializujące się w osadach miejskich przyjmują postać 'nowoczesnego nurtu międzynarodowego'. Tym samym zaobserwować można szybko postępujący proces unifikacji, zagrażający naruszeniem autentyczności historycznych przestrzeni miejskich do tej pory stanowiących o ich unikalnym charakterze.

Domknięciem uprawomocnienia autentyczności miasta jest jej zachowanie na poziomie/wymiarze ekspresyjnym. Poziom/wymiar ten sam w sobie jest niejako bezpośrednim dopełnieniem koniecznej asymilacji wymiaru materialnego oraz wymiaru konstruktywnego, a tym samym stanowi swoistą ekspresję fizycznych atrybutów oraz procesu kreacji i re-kreacji przestrzeni miejskiej w czasie [8]. Zważywszy na fakt, iż 'autentyczność' może być postulowana jako wyznacznik doświadczenia któremu ulega odbiorca podczas zwiedzania i kontaktu z obiektem dziedzictwa kulturowego (czyli 'autentycznemu doświadczeniu'), pozostaje dyskusyjnym sama forma ekspresji autentyczności i jednocześnie możliwość jej ewentualnego zafałszowania. W konsekwencji niezwykle istotnym pozostaje właściwe rozróżnienie przekazu autentycznego od przekazu zniekształconego, gdzie ten ostatni może uzyskać ów status zarówno w sposób przypadkowy jak i również zamierzony.

Nawiązując do Zancheti, Lira oraz Piccolo należy zatem zwrócić uwagę na fakt, iż nawet jeżeli autentyczność ujmujemy jako swoistą 'wewnętrzną' charakterystykę obiektu, może dojść do jej zafałszowania podczas procesu doświadczania tego obiektu [8]. Wydaje się zatem, że weryfikacja autentyczności powinna przebiegać na poziomie relacji pomiędzy percepcją i kondycją 'bycia' obiektu. Tym samym doświadczenie, czy też ekspresyjność danego obiektu, powinny być konstruowane przy zachowaniu specyficznego poziomu oglądu świadomości i poprzez ujmowanie obiektu jako będącego autentycznym, ale też równolegle poprzez wiedzę zarówno o materialnej charakterystyce jak i jego konstruktywnej strukturze, a także biorąc pod uwagę wszelki kontekst, historyczny proces, przestrzeń oraz czas [8].

Reasumując, ekspresyjny wymiar autentyczności rozgrywa się w napięciu pomiędzy obiekt (przedmiot) - podmiot (odbiorca). I tak w odniesieniu do danego założenia miejskiego wymiar ów obrazuje zdolność do manifestacji jego mieszkańcom oraz odwiedzającym turystom danego sposobu życia z przeszłości, z konieczności odniesionego bezpośrednio do przestrzeni wyznaczonej przez granice tej właśnie osady i jednocześnie utrzymywanego w perspektywie zachowania jej istotowej tożsamości, dzięki czemu staje się on powszechnie zrozumiały i intersubiektywnie odczuwany. Warunkiem koniecznym ekspresyjnego wymiaru autentyczności jest zatem jego powszechne rozpoznanie i społeczna komunikowalność, w aspekcie których unaoczniony zostaje pewien zakres znaczeń zrozumiałych dla każdej jednostki ludzkiej [8]. 


\section{Uwagi końcowe}

Uchwycenie i rozpoznanie autentyczności miasta gwarantuje właściwy sposób jego zarządzaniem, zarówno od strony zabiegów konserwatorskich jak i planowanych działań architektonicznych oraz urbanistycznych. Jest jednocześnie podstawą jakiegokolwiek procesu zmierzającego do 'fizycznych' interwencji dotyczących poszczególnych atrybutów, takich jak modyfikacja form ich ekspresji, bowiem niewłaściwe odczytanie autentyczności prowadzi do szybkiego zaniku charakteru przestrzeni urbanistycznej.

Pytanie o autentyczność miasta jest w rzeczy samej pytaniem o coś, co jest przynależne jego atrybutom i przez te atrybuty wyrażone. Jednocześnie autentyczność miasta nie jest czymś jednoznacznie ustalonym w swej ostatecznej krystalizacji, bowiem jako zależna od kontekstu, miejsca i czasu musi być ona wciąż na nowo odczytywana przez każdą społeczność. W konsekwencji autentyczność nie jest czymś, co może być dodane do miasta - autentyczność istnieje ponieważ miasto 'wyraża' siebie dla nas.

\section{Literatura}

[1] Brandi C.: Teoria restauracji (tłum. Kijanko M.), Międzyuczelniany Instytut Konserwacji i Restauracji Dzieł Sztuki, Warszawa 2006.

[2] Burnett K.: Patrimonio, autenticidade e historia, Questoes de qualidade nasatracoes de visitacao ao patrimonio, Roca, Sao Paulo, Brazylia, 2001.

[3] Ferrara A.: Reflective authenticity - rethinking the project of modernity, Routledge, Londyn, WielkaBrytania, 1998.

[4] Jamal T., Hill S.: Developing a framework for indicators of authenticity: the place and space of cultural and heritage tourism, Asia Pacific Journal of Tourism Research, nr 9/4, 2004, s. 353-371.

[5] Jokilehto J.: Considerations on authenticity and integrity in World Heritage context, City\&Time, nr 2/1, 2006, s. 1-14.

[6] Philippot P.: La teoria del restauro nell'epoca della mondializzazione, Arkos: scienza e restauro, nr 3/1, 2002, s. 14-17.

[7] Taylor C.: The ethics of authenticity, Harvard University Press, Cambridge, Wielka Brytania, 1992.

[8] Zancheti S., Lira F., Piccolo R.: Judging the authenticity of the city, /w:/ StanleyPrice N., King J. (ed.): Conserving the authentic: essays in honour of Jukka Jokilehto, ICCROM Conservation Studies, nr 10, Rzym, Włochy, 2009, s. 163-170. 


\section{THE ISSUE OF AUTHENTICITY IN THE PRESERVATION}

\section{OF HISTORIC URBAN AREAS}

\section{S u m m a r y}

Capturing the authenticity of the city guarantees an appropriate way of managing it, both from conservation operations and planned architectural and urban planning activities. This article examines the conditions and levels at which the authenticity of a city manifests itself, and identifies the ways in which this manifestation is expressed, and how the process can be falsified and evaluated.

Keywords: city, authenticity, identity, preservation

Przestano do redakcji: 09.06.2017 $r$.

Przyjęto do druku: 01.09.2017 r. 